\title{
ガングリオンによる肩甲上神経麻痺の一症例
}

一超音波エコー下での穿刺術の治療経験一

小倉記念病院

藤 井 康 成·小倉 雅

鹿屋体育大学保険管理センター

奥 脇 透

鹿児島大学整形外科

酒匂崇

\section{A Case Report on Suprascapular Nerve Paralysis Caused by a Ganglion}

by

Yasunari Fujii and Tadashi Ogura

Ogura Memorial Hospital

Tohru Okuwaki

National Institure of Fitness and Sports in Kanoya

Takashi Sakou

Department of Orthopaedic Surgery, Kagoshima

University School of Medicine

We report one case who presented with suprascapular nerve paralysis caused by a ganglion.

The patient is a 20 year-old male, and a high-level athlete. He complained of pain and weakness of his right shoulder, and presented with marked atrophy of infraspinatus muscle. MRI and ultrasonography showed a cystic legion in supraspinatus fossa. We treated with a puncture of the ganglion safely under ultrasonography.

Eight months after puncture he has no signs of relapse and has returned to full sporting function.

In this study we show that ultrasonography is a useful method for diagnosis and treatment of suprascapular nerve paralysis caused by a ganglion.

Key words : ガングリオン (Ganglion), 肩甲上神経麻痷 (Suprascapular Nerve Paralysis), 超音波エコー（Ultrasonography）

は じめ に

肩甲上神経麻痺の原因は，その神経の走行の特異性 より, entrapmentによるものが広く知られているが, 近年，ガングリオンによる圧迫も注目され，その報告 も散見される、今回，肩関節に愁訴を有したスポーツ 選手の筋力訓練中に，発生したガングリオンによる肩
甲上神経麻痺の一症例を経験したので報告する。

症例

症例は 20 歳, 男性. 現役の棒高跳びの選手である 両肩の軽い疼痛と脱力感を主訴に, 平成 7 年 11 月当 院を受診した。両肩に外転外旋時, 軽度の apprehensionを認め, loose shoulderの診断で, 腱板の 


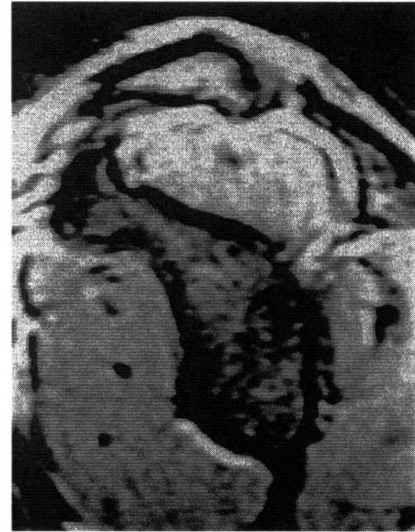

a.

図 1 発症前後における MR 像

a. 発症前の $\mathrm{T} 2$ 強調像

b. 発症後の $\mathrm{T} 2$ 強調像

c. 発症後の $\mathrm{T} 1$ 強調像

発症後の MRIにて棘上窩に T1-low，T2-highの占拠病変を認める.

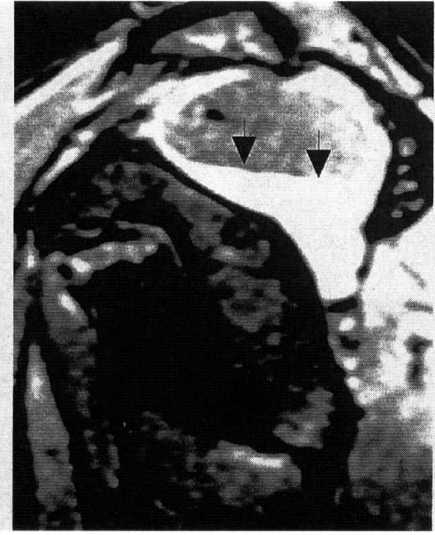

b.

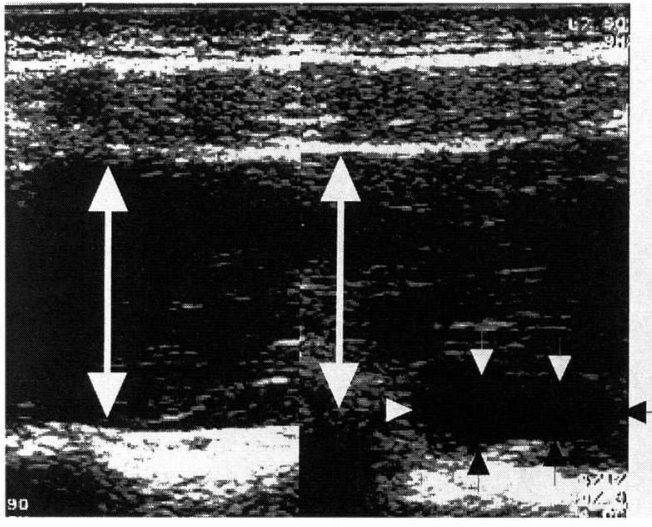

健 側

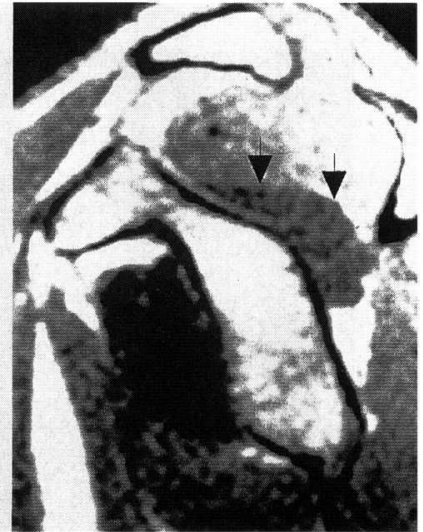

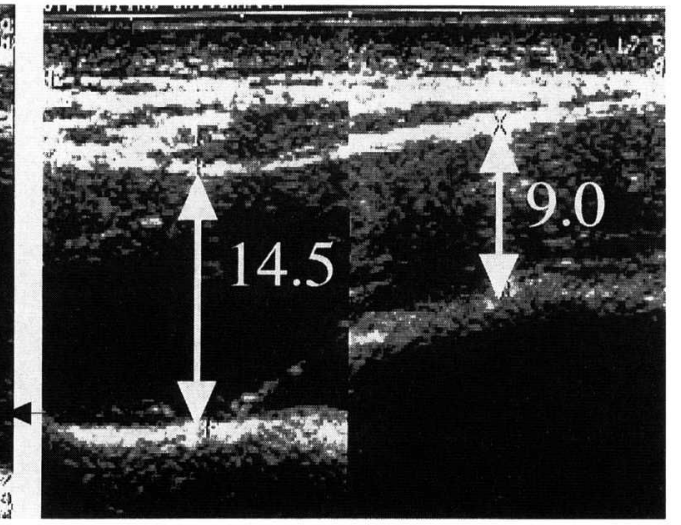

健 側

患 側

図 2 棘上・棘下筋の超音波エコー像

$\leftrightarrow:$ 筋層の厚さ $(\mathrm{mm}) \rightarrow$ : ガングリオン部

患側の棘下筋の筋萎縮を認める.

健側 : $14.5 \mathrm{~mm}$ 患側 : $9.0 \mathrm{~mm}$

筋力強化訓練の指導を行った。当時の MR 像では局 関節周辺に特に異常を認めなかった（図 1-a)。平成 8 年 10 月, 次第に右肩関節の疼痛拉よび挙上時の脱力 感の増悪を認めたため再診。右棘下筋の萎縮および外 旋筋力の低下を認め，さらに超音波エコー下で棘上窩 の $3 \mathrm{~cm}$ 深部に $0.7 \times 1.5 \mathrm{~cm}$ の占拠性病変を認めたた
め（図 2), 再度 MRI を撮像した，肩甲切痕後方の䊂 上筋の深部, 肩甲上神経の走行部付近に, T1-low, T2-high を示す囊腫様の病変を認め（図 1-b, c)，ガ ングリオンの診断のもと, 超音波ガイド下に, 穿刺術 を施行した（図 3 ). 現在, 穿刺術後 8 カ月で疼痛は軽 減, 筋力および筋萎縮も改善し, 競技に復帰している. 


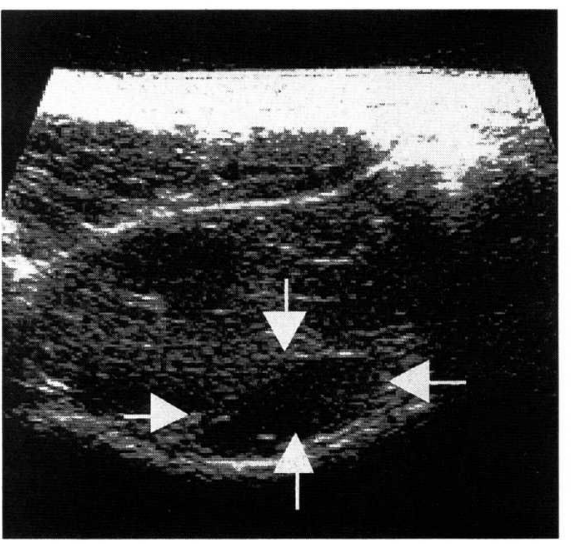

a. 穿刺前

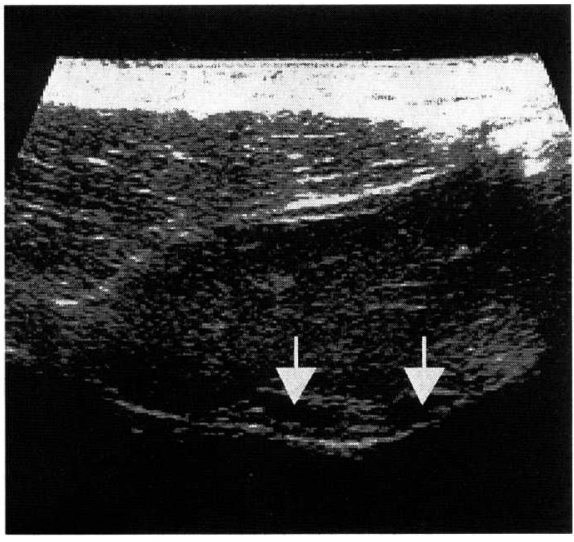

b. 穿刺後

図 3 ガングリオンの超音波エコー像

$\mathrm{a}$ : 棘上窩の $3 \mathrm{~cm}$ 深部に, $7.0 \times 14.5 \mathrm{~mm}$ のガングリオンを認めた.

$\mathrm{b}$ : 穿刺後,ほぼ消失した.

考

察

肩甲上神経麻痛は, Kopell らの報告以来, 絞扼性 神経障害が主な原因であった。その絞扼部位としては scapular notch と spinogrenoid notch 2 力所 であり，背景に肩甲切痕の形態異常，肩関節の過度の 運動, over head からの投球動作の反復などによる 神経の絞扼ならびに損傷が挙げられる。一方，ガング リオンの圧迫による肩甲上神経麻疩の報告は, 荻野ら によると 1992 年時点で，29 例を渉猟するのみであっ たとされ2，比較的稀な疾患と考えられる．ガングリ オンの発生部位としては肩甲切痕近位より, 局甲棘基 部外側部までのいずれの部位でも生じうるが，その報 告のほとんどは棘上窩より局甲棘基部外側部であ $る^{1212177)}$ ，そのため神経圧迫部は棘上筋への神経分岐以 遠であり，臨床症状は棘下筋の筋萎縮のみを認める報 告が多い. 我々の症例も棘下筋の筋萎縮と肩の外転外 旋力低下を認めるのみであった。

ガングリオンの診断に際しては, 浜らの報告の如く ${ }^{6)}$, 超音波エコーが有用で, 原因不明の肩関節痛, 筋力低 下を認める場合, 積極的なエコー下での精査が勧めら れる，局在に関しては，エコーならびに MRI が有用 で，その位置および大きさを知るのに適している. 現在，ガングリオンによる肩甲上神経麻痷は，観血
的摘出術が主流であるが，本症例はスポーツ競技の継 続を強く希望したため, 保存的に超音波エコー下で穿 刺術を行った，その手技は比較的容易で, 術後8力月 の短期 follow ではあるが，その後のエコーでの精査 でも再発傾向は認めていない，佐藤らは手部ガングリ オンの長期 follow において, 7 年以上経過した保存 例の約 $80 \%$ は消失したとして抢り ${ }^{3)}$ ，この意味では， 本症においても穿刺術を併用しながらの保存的治療は 有用かもしれない。また，穿刺に伴う神経損傷の可能 性については慎重な超音波エコー下での観察により， ガングリオンと神経との位置関係の把握もでき，比較 的安全に施行できると考えている（図 4).

\section{結語}

(1)ガングリオンによる肩甲上神経麻疩の一症例を経 験した.

(2)保存的に超音波エコー下で穿刺術を施行したが， その手技は比較的容易であった。

(3)超音波エコーは，ガングリオンによる肩甲上神経 麻痷の診断，治療およびその後の経過観察に有用と考 える.

\section{参 考 文 献}

1）大塚和孝ほか：ガングリオンによる局甲上神経麻㾝の 

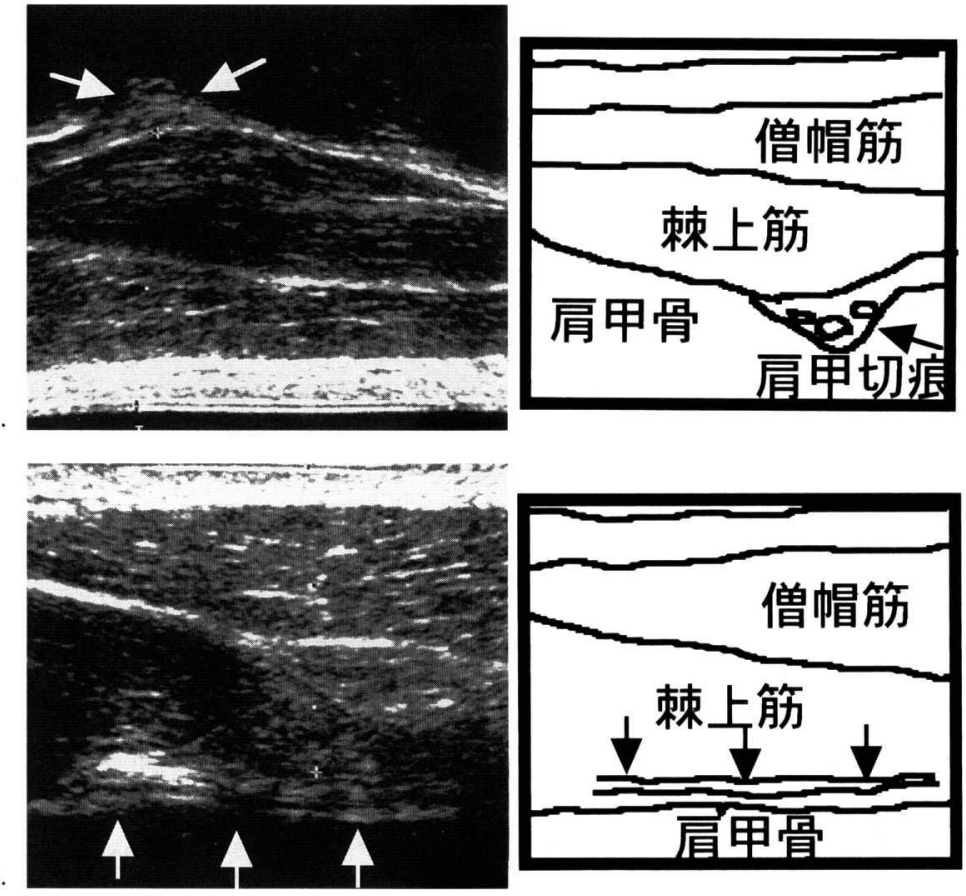

図4 棘上浻における肩甲上神経の超音波エコー像
a. 肩甲切痕部での前額断
b. 神経の走行に沿った矢状断
ヒは肩甲上神経を示す

3 例. 整外と災外, $43: 947-951,1994$

2）荻野利彦ほか：ガングリオンによる肩甲上神経麻痷. 関節外科, $11: 485-492,1992$.

3）佐藤伸一ほか: 手部ガングリオンの長期成績一保存的 治療を中心として. 整形外科, $42: 1712-1716,1991$.

4）玉井和哉ほか: ガングリオンによる棘下筋単独麻痷の 1 症例. 整形外科, $36: 699-703,1985$.
5）永井环己ほか：肩甲上神経麻瘏の 2 例. 整- 災外, 37 : 219-222, 1994.

6）濱 弘道ほか：肩甲上神経麻痷に対する超音波断層法. 別冊整形外科, $13: 317-318,1988$.

7）三浪三千男ほか：ガングリオンによる肩甲上神経麻㾝 の 1 例. 臨整外, $17: 1273-1276,1982$. 